Sharif University of Technology
Scientia Iranica
SCIENTIA
I RAN I CA
Transactions A: Civil Engineering
www.scientiairanica.com

\title{
Long-term flexural behaviour of reinforced baked clay beams
}

\author{
N.A. Lakho and M. Auchar Zardari* \\ Department of Civil Engineering, Quaid-e-Awam University of Engineering, Science and Technology, Nawabshah, Sindh, Pakistan.
}

Received 26 April 2015; received in revised form 9 November 2015; accepted 5 April 2016

\section{KEYWORDS \\ Baked clay beams; \\ Sustained loads; \\ Ultimate loading \\ capacity; \\ Deflection; \\ Cracks.}

\begin{abstract}
Clay is a low cost and environment-friendly material for construction. On firing, it gets hard and attains compressive strength as high as normal concrete. This paper presents the flexural behaviour of singly reinforced baked clay beams under longterm sustained loads. The loads applied at midspan of these beams were $30 \%, 40 \%$, and $50 \%$ of their short-term failure load for a period of 360 days. The results show that the rate of deflection, formation of cracks, and their stabilization was completed in a certain period of time depending on the intensity of the long-term sustained loads. In the first and second loading conditions, this period of opening and stabilization of cracks was 100 and 77 days, respectively. Then, the deflection increased with a decreasing rate. While in the case of $50 \%$ of loading condition, the period of formation and stabilization of cracks was reduced to only 50 days, and then these cracks became dormant and no new crack was developed with respect to time. After that, negligible midspan deflection was observed with time. In addition to this, the deflection in these beams was more compared to the estimated long-term deflection according to ACI code.
\end{abstract}

(C) 2017 Sharif University of Technology. All rights reserved.

\section{Introduction}

Baked clay has been utilized as building construction material since the ancient time in the world; for example, in Ziggurats of Mesopotamia, Moen-Jo-Daro, Great Wall of China, and the Minarets of Islam (see Figures 1-4). About 30\% of the people in the world use baked clay houses for their shelter [1].

Baked clay is a non-combustible and non-decaying material. It is fired at high temperatures. Therefore, strong bonds are formed which make it resistant to weathering [2]. In baked clay, absorption and release of heat occur gradually. This implies that such houses maintain cooling in hot weather and warmth in cold. Therefore, there may be no significant need for artificial heating and cooling in baked clay houses. Energy

*. Corresponding author. Tel.: 00923003030294

E-mail addresses: nawablakho@gmail.com (N.A. Lakho); muhammad.auchar@quest.edu.pk (M. Auchar Zardari) saving, in terms of less heating and cooling, may result in good environmental conditions. Baked clay has good acoustic properties to reduce noise [3]. Baked clay is long-lasting building material. This suggests that buildings made of clay, with low maintenance, can last for many hundred years [4].

Baked clay is considered to be a potential alternative to concrete in order to reduce construction cost of houses in plain areas of Pakistan [5-9]. Previous studies indicate that baked clay could be used as a substitute for concrete, and its cube crushing strength obtained was comparable to that of concrete [10]. It is a novel idea to use reinforced baked clay as building construction material; therefore, it is necessary to understand its structural behaviour under short-term as well as long-term sustained loads.

The effects of long-term sustained service loads can cause various levels of deflection depending upon the property of material from which the structure is made, intensity of loading, environmental conditions, 


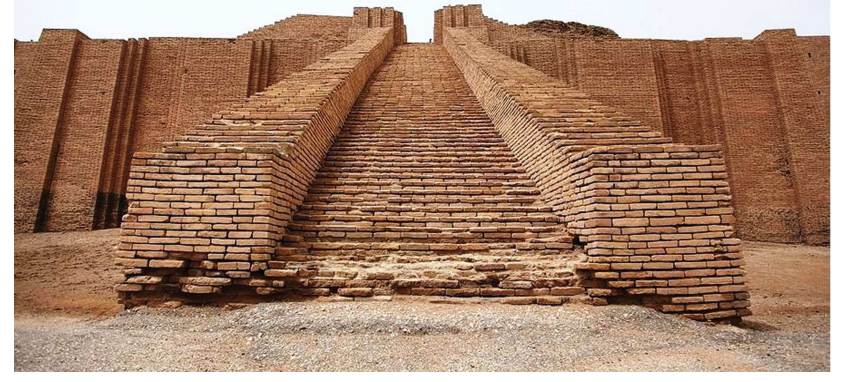

Figure 1. Baked clay bricks used in Ziggurats of Mesopotamia (photo courtesy of google images).

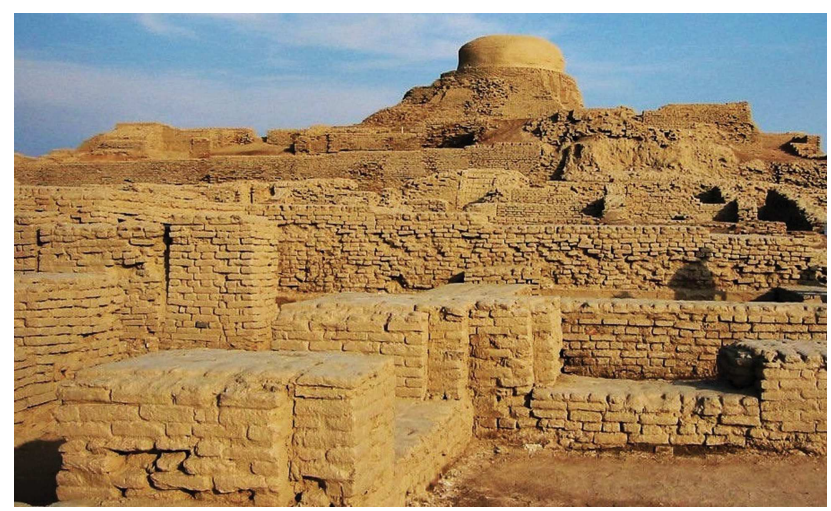

Figure 2. Baked clay bricks used in Moen-Jo-Daro (photo courtesy of google images).

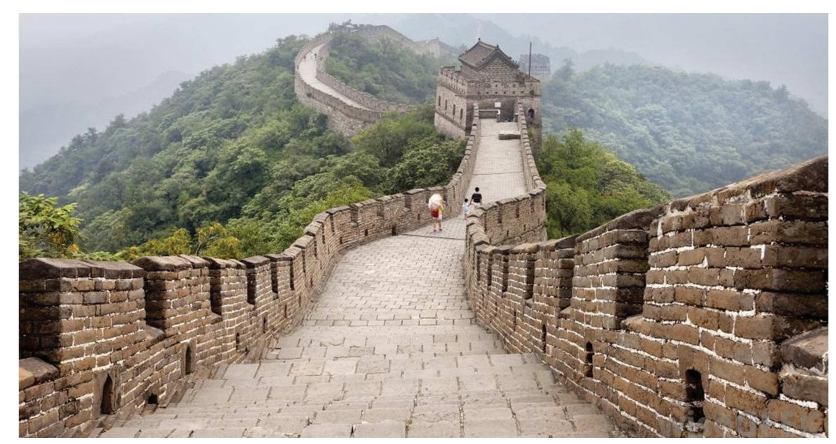

Figure 3. Baked clay bricks in Great Wall of China (photo courtesy of google images).

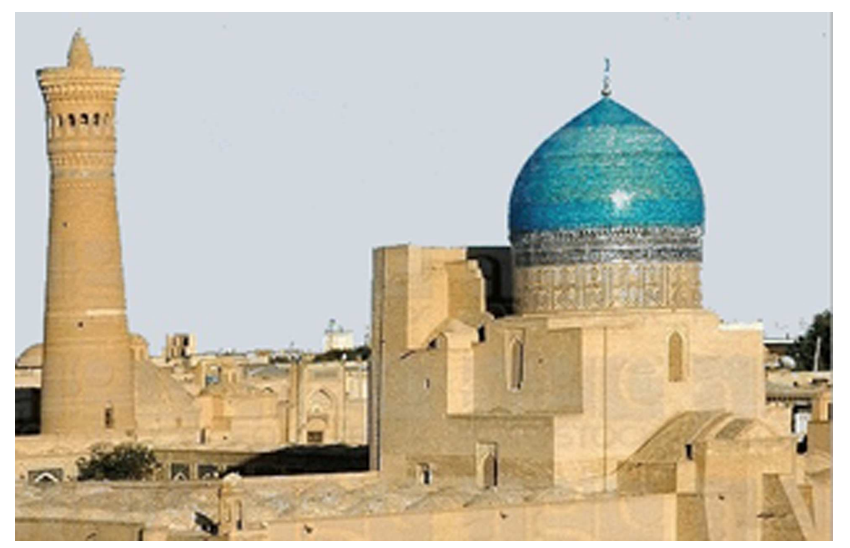

Figure 4. Baked clay bricks used in Kalyan mosque at Bhukara, Uzbekistan (photo courtesy of google images). and duration of the loading [10]. The deflection of beams should be estimated accurately because it can damage the structural and nonstructural elements of the building [11]. Unfortunately, there is no literature available regarding the long-term study of Reinforced Baked Clay (RBC) beams, to the best of knowledge of the authors. On the other hand, the structural behaviour of the Reinforced Cement Concrete (RCC) beams has been studied on large scale [12-24] and numerical models are developed to simulate the behaviour of concrete on long-term loading [25-27].

The deflection in reinforced concrete beams is influenced by creep and shrinkage of concrete, which again depends on environmental conditions, humidity, type of cement, water cement ratio, age of concrete, amount of compressive steel, size of specimen, and support conditions [28-29].

The prediction of deflection of beams is a very complex problem which needs a practical knowledge of the material from which the beam is made and the effects of various boundary conditions on the beam throughout its service life [30-32].

Regarding the short-term flexural behaviour of laboratory-sized singly Reinforced Baked Clay (RBC) beams, which were properly grouted, the study shows that the majority of these beams failed in shear when they were not properly compacted and consolidated at the time of casting and baked at the temperature less than $900^{\circ} \mathrm{C}[7]$.

To get insight into the long-term behaviour and seek solution to this shear failure in RBC beams, this study was conducted and 18 beams were tested, out of which 12 beams were tested in short-term loading, and the remaining 6 were loaded with different levels of loads for a period of 360 days.

\section{Materials and method}

\subsection{Beam specimen}

Indigenous clay was quarried from the premises of Civil Engineering Department Laboratory of Quaid-eAwam University of Engineering Science and Technology Nawabshah, Sindh, Pakistan. The clay samples were taken at the depth of $1.25 \mathrm{~m}$, so that the debris of construction materials and aggregates may not be mixed with the quarry (Figure 5). This clay was properly dried and pulverized (Figure 6) before being mixed with $30 \%$ of pit sand (Figure 7 ). Potable water up to $22 \%$ was added and mixed in pan mixer for 15 minutes. This moist clay was covered under a plastic sheet for 24 hours for proper maturing. Then, beams were cast in a mould having size of $2000 \times 300 \times 150$ $\mathrm{mm}$, and perforations were made for reinforcement at the time of casting. The beams were compacted at the compaction of $6 \mathrm{~N} / \mathrm{mm}^{2}$. The beams were then dried and baked in a kiln present in the laboratory 


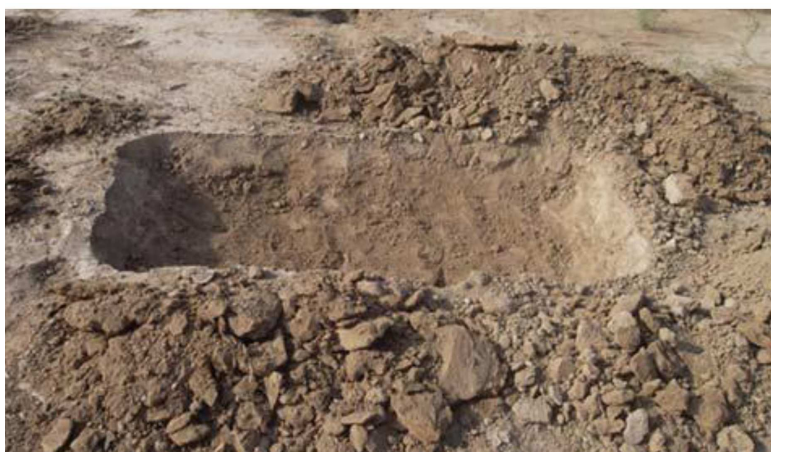

Figure 5. Indigenous clay is being excavated at a depth of $1.25 \mathrm{~m}$ to prepare paste for casting of beams.

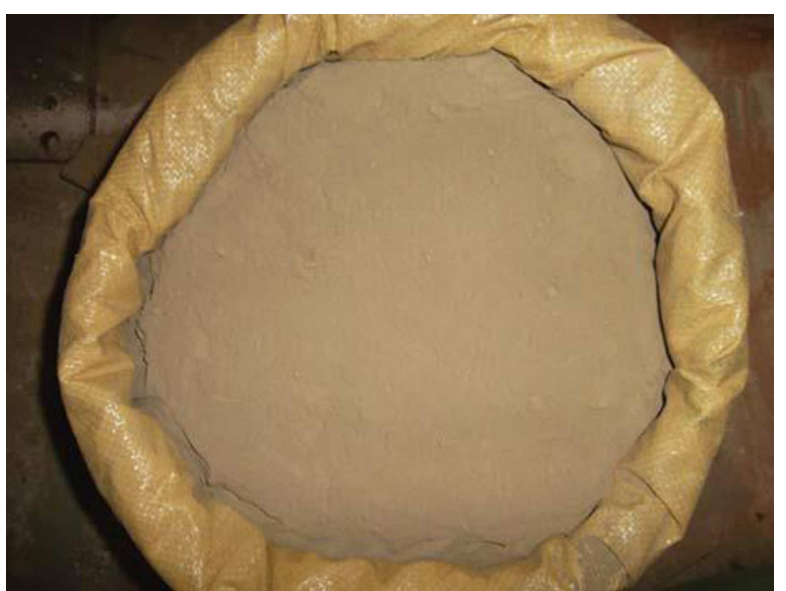

Figure 6. View of clay after being powdered in pulverizer.

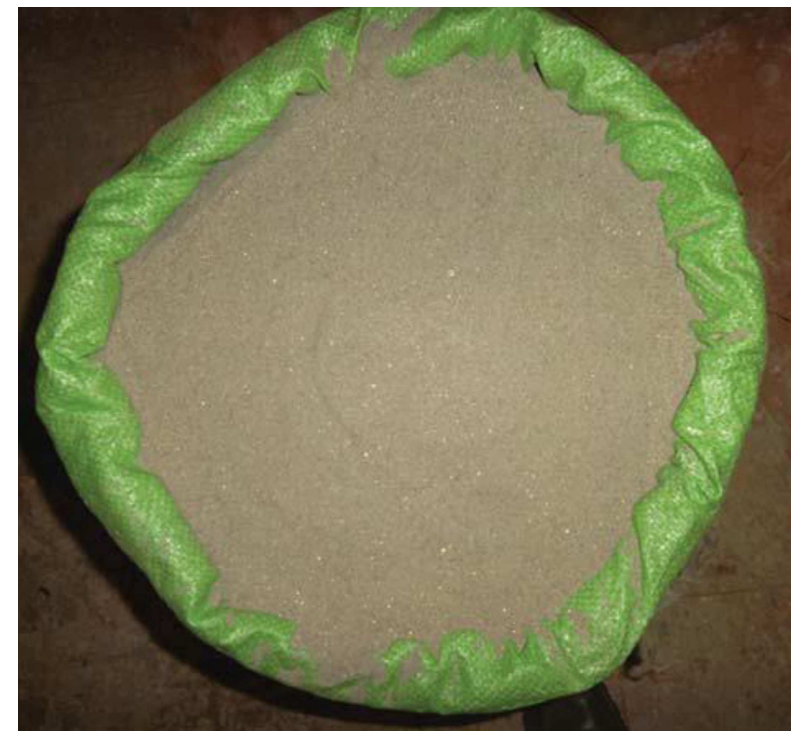

Figure 7. View of pit sand that was added in clay to prepare mixture to cast beams.

(Figure 8). The baking process of beams was followed using ASTM C62 [33]. These beams were singly reinforced as the under-reinforced beam section. The beams were tested for short-term loading up to failure in order to determine their load carrying capacity.

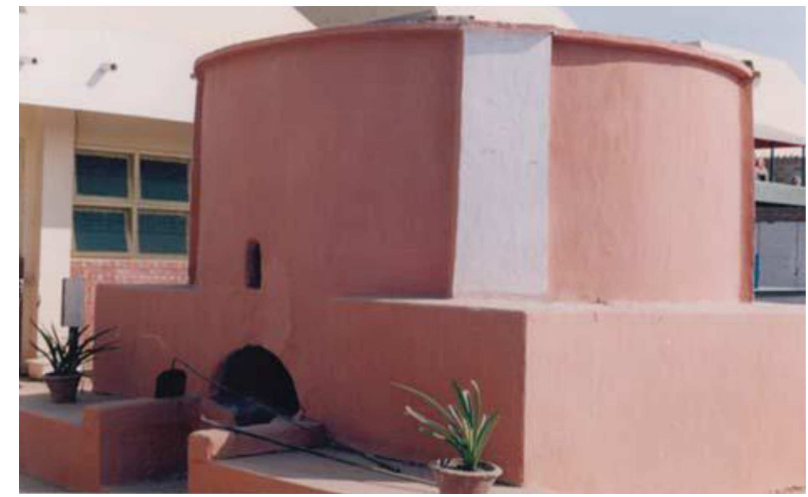

Figure 8. View of laboratory kiln for baking clay beams.

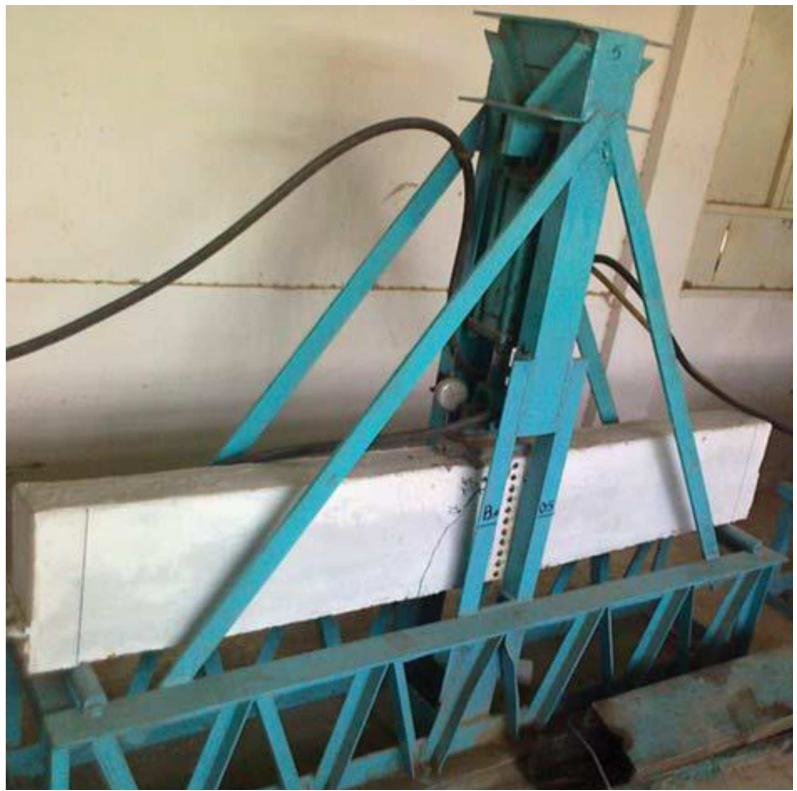

Figure 9. Test set up for long-term loading of reinforced baked clay beams.

The reinforcing bars were welded with $150 \times 150 \mathrm{~mm}$ anchor plates at both ends of the beam. The size of the beams after drying and shrinking was $1850 \mathrm{~mm}$. The total linear shrinkage observed during drying and baking process of clay beams varied between $0.6-6 \%$, depending on the amount of water added in clay and rate of compaction during casting.

\subsection{Long-term testing frame}

Strong and stiff testing steel frames were designed and fabricated for testing of laboratory size beams for longterm loading (see Figure 9). The testing frames are composed of (i) a double truss section for supporting the beam at base; (ii) a double vertical post channel section to carry and support the jack cylinder in a correct vertical position for load application on beam; (iii) four tension stiffening steel plates which join the ends of truss section to the top of vertical posts in order to increase the strength and stiffness of the frame; (iv) a very strong hydraulic jack for the application of long- 
term sustained loads; (v) a load cell to show the rate of loading applied at the beam; and (vi) a dial gauge to record the deflection of the beam at midspan due to time-dependent loading.

\subsection{Test set-up}

Six reinforced baked clay beams were tested in a longterm sustained loading condition. In long-term testing frames, concentrated load on simply supported beam was applied at its midspan. The loading was applied by hydraulic jack operated with hydraulic pump. To determine the deflection at midspan of the RBC beams, the frame was attached to deflection dial gauge. The beams were divided into three groups as A, B, and $\mathrm{C}$, according to the rate of loading. The intensity of loading in long-term testing of RBC beams was $30 \%$, $40 \%$, and $50 \%$ of the ultimate load carrying capacity of these beams in short-term loading. Two beams were tested in each case. The load was sustained on these beams for 360 days and data of deflection were recorded with time.

\section{Results and discussions}

\subsection{Short-term loading}

Six RBC beams singly reinforced, as under-reinforced section, were tested in short-term loading. It was observed that majority of the beams failed only in flexure by opening a single crack in tension zone, while, in some beams, this flexural crack was opened at a distance less than the effective depth from the midspan in tension zone. No sign of shear failure was observed in any of the beams tested in short-term loading. The beams failed at average ultimate load of $80 \mathrm{kN}$ applied at midspan.

\subsection{Long-term loading}

For the observation of structural behaviour of RBC beams under long-term sustained loads, six beams were tested in three-point loading. This load was sustained on these beams for 360 days. These beams were divided into three groups as Group A, B, and C, according to the intensity of sustained loading. There were two beams in each group. There were three intensities of loading as $30 \%, 40 \%$, and $50 \%$ of the ultimate capacity of loading on these beams in short-term loading.

\subsubsection{Time-deflection response of reinforced baked clay beams}

Group A contains beams $\mathrm{BL}_{1}$ and $\mathrm{BL}_{2}$. These beams were loaded up to $30 \%$ of the ultimate load carrying capacity of the beams in short-term loading. The deflection of the beams with respect to time is shown in Figure 10. The results show that the long-term deflection of the beams was about $1.12 \mathrm{~mm}$ after 360 days of loading (Figure 10). Group B contains beams $\mathrm{BL}_{3}$ and $\mathrm{BL}_{4}$. These beams were loaded up to $40 \%$ of

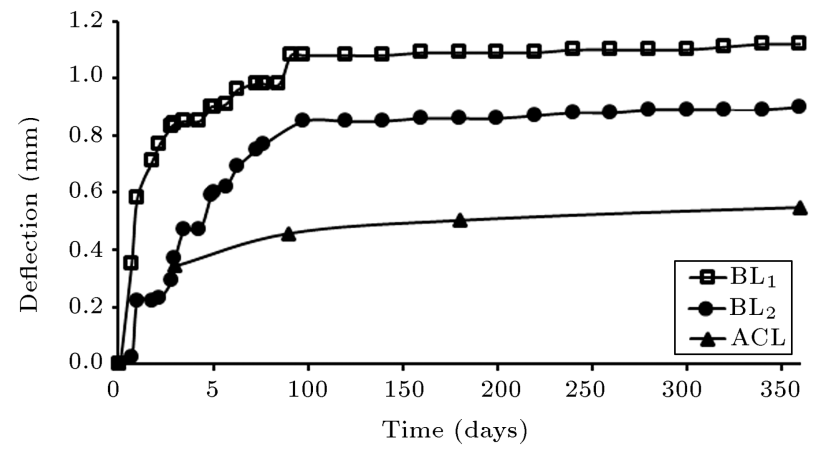

Figure 10. Long-term deflection of beams loaded at $30 \%$ of the ultimate load carrying capacity.

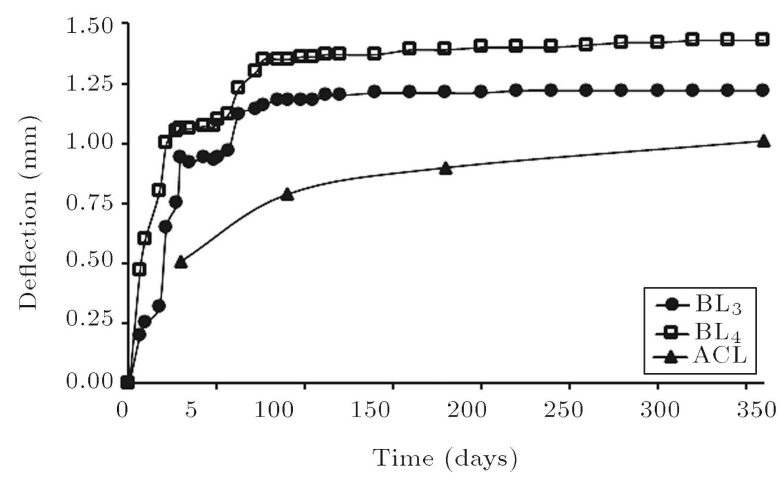

Figure 11. Long-term deflection of beams loaded at $40 \%$ of the ultimate load carrying capacity.

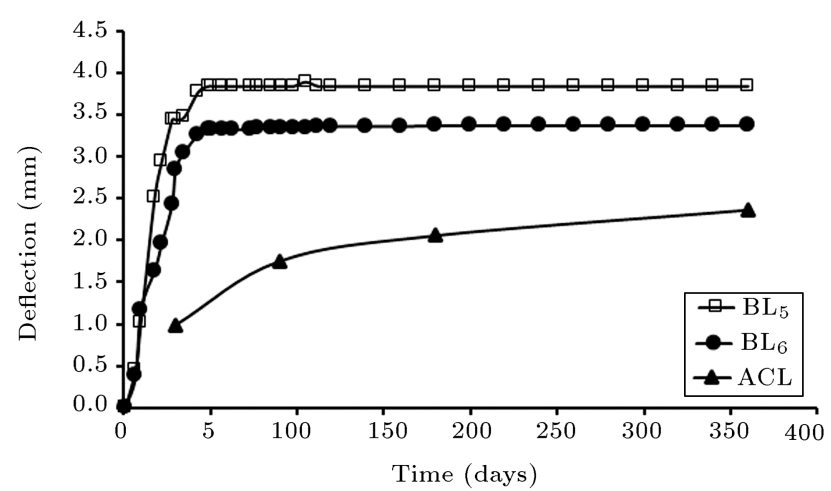

Figure 12. Long-term deflection of beams loaded at $50 \%$ of the ultimate load carrying capacity.

the ultimate flexural load carrying capacity and showed deflection of $1.43 \mathrm{~mm}$ after sustained loading of 360 days ( Figure 11), the beams $\mathrm{BL}_{5}$ and $\mathrm{BL}_{6}$ comprised Group C. This group of beams was loaded at $50 \%$ of the ultimate load, which resulted in maximum midspan deflection of $3.84 \mathrm{~mm}$ after 360 days (Figure 12). Figures 10-12 show that the deflection increases with the increase of the level of loading and time.

Figures 10-12 show that more rate of increase of midspan deflection was observed in the beams loaded with less loading intensity (30\% and $40 \%$ ) as compared to the beams loaded with higher loading intensity $(50 \%)$. This increase in the rate of midspan deflection 
may be attributed to the idea that these RBC beams have a certain deflection capacity at midspan. In the case of higher loading intensity, the capacity of deflection of beam occurred in less duration of time, whereas, in the case of less loading intensity, a small instantaneous deflection occurred and the remaining part of the deflection capacity occurred due to time of loading.

The rate of increase of deflection in the case of beams $\mathrm{BL}_{5}$ and $\mathrm{BL}_{6}$, loaded with $50 \%$ of loading intensity, is more in its initial age of loading and reached its higher levels $(3.84 \mathrm{~mm}$ and $3.37 \mathrm{~mm}$, respectively) in only 50 days. No remarkable increase in midspan deflection was observed with the time of loading (Figure 12). The rate of deflection became asymptotic after the age of loading of 50 days and continued to remain unchanged for the remaining period of loading of 360 days. In the case of the beams loaded with smaller loading intensity, less rate of midspan deflection was observed as compared to the beams $\mathrm{BL}_{5}$ and $\mathrm{BL}_{6}$. The midspan deflection reaches its maximum values of 1.08 and $0.85 \mathrm{~mm}$ in beams $\mathrm{BL}_{1}$ and $\mathrm{BL}_{2}$, respectively, in about 100 days. In beams $\mathrm{BL}_{3}$ and $\mathrm{BL}_{4}$, the instantaneous part of the socalled deflection capacity occurred within a duration of 77 days and reached up to $1.35 \mathrm{~mm}$ and $1.16 \mathrm{~mm}$, respectively. After this period, the remaining part of total capacity of deflection of these beams was caused by time of loading. In addition, after the age of loading of 360 days, the total midspan deflection in beams $\mathrm{BL}_{3}$ and $\mathrm{BL}_{4}$ reached $1.43 \mathrm{~mm}$ and $1.22 \mathrm{~mm}$, respectively. Moreover, in the case of Group $\mathrm{C}$, the deflection capacity of the beams occurred in very small duration of time of 50 days and reached $3.84 \mathrm{~mm}$ and $3.37 \mathrm{~mm}$, respectively. But, no increase in deflection was observed after this period up to the loading period of 360 days.

The long-term deflection was calculated analytically using ACI code [30] and was compared with the experimentally determined values (Figures 10-12). According to Figures 10-12, the ACI curves show very small deflection as compared to experimental values. This may be attributed to the difference in type of material (i.e., baked clay) used in the beams. This formula of deflection, according to ACI code, was formulated for concrete which is non-homogeneous material, whereas the baked clay is purely homogeneous material after baking. The aforementioned idea needs further research, and such formulas for prediction of deflection of RBC beams must be deciphered. Occurrence of cracks in the beams may be another possible cause of these higher values of deflection obtained experimentally. Baked clay is a strain sensitive material and these Reinforced Baked Clay (RBC) beams were cracked at small load of $30 \%$ of the ultimate one. After the cracking process, the tensile stress in the beams was transferred to the tensile reinforcement. Thus, the beams showed more deflection.

\subsubsection{Crack-opening development}

The cracking of the beams, in majority of cases, was started by opening of single crack near the center of the beam below loading point at bottom. This crack propagated upward to reach the loading plate at the top of beam in compression zone. In other cases, one or two cracks were opened at a distance of less than the depth of beam from center. In the case of two cracks, these cracks propagated upward converging towards midpoint of beam in compression zone to meet at the center of loading plate. The increased rate of deflection and opening of cracks of RBC beams was observed mainly during the first 100 days of the sustained loading in the case of group A. After the first 100 days of loading, these cracks were stabilized and became dormant and a very small increase in midspan deflection was observed. In the case of beams of group $\mathrm{B}$, the opening of cracks was completed within the first 77 days of loading history. After this period, these cracks stabilized and became dormant. A very small midspan deflection was observed in this group of beams as compared to that of Group A after 77 days, whereas, in the case of beams of Group C, the total deflection occurred in only a small period of 50 days and all the cracks were opened and stabilized in this period. No new crack was observed to open in tension zone after this period. These cracks remained dormant for the remaining period of sustained loading of 210 days.

\subsection{Practical importance of reinforced baked clay}

In Reinforced Baked Clay (RBC) beams, neither compression reinforcement nor shear reinforcement was needed, forming more than $50 \%$ of the total area of reinforcement in the beams. Saving, in terms of reinforcement cost, can be achieved by using $\mathrm{RBC}$ rather than reinforced cement concrete, since baked clay is $20 \%$ lighter than that of concrete. Hence, about $20 \%$ of reinforcement is saved that is required to support self-weight of the beam.

In this study, the reinforcing agent was steel, which is corrodible in nature in the presence of moisture. If non-corrodible material, such as Fiber Reinforced Polymer (FRP), is used instead of steel, reinforced baked clay buildings can be designed to last for more than a thousand years.

\section{Conclusions}

The main conclusions drawn by studying Reinforced Baked Clay (RBC) beams under long-term sustained loading for a period of 360 days are: 
1. Mode of failure of RBC beams was a purely flexural one;

2. Failure commenced with (in the majority of cases) the opening of single crack from the bottom below the loading plate. This crack advanced upward to reach the loading plate at the top compression fiber;

3. In some cases, one or two cracks were opened at distance less than the depth of beam from midspan. These cracks advanced upward converging inwards in compression zone to meet at the center of loading plate;

4. All the beams were cracked when the loading reached $25 \%$ of the ultimate capacity of RBC beam tested in short-term loading;

5. The rate of deflection and opening of cracks of RBC beams depends upon the rate of suspended loading within 100,77 , and 50 days for the beams loaded with $30 \%, 40 \%$, and $50 \%$ of the ultimate load carrying capacity of the beams, respectively;

6. In case of the RBC beams loaded with $30 \%$ and $40 \%$ of short-term failure, a small increase in midspan deflection was observed with time of loading. The cracks became dormant and no new crack was observed when loading up to 360 days;

7. The deflection, observed in the beams loaded with $50 \%$ load after 50 days, was negligible as compared to the deflection observed in beams loaded with $30 \%$ and $40 \%$ of the loading capacity of the beams. After 50 days of the loading time, the cracks became dormant and no significant deflection was observed in the age of loading up to 360 days.

\section{Acknowledgements}

The authors would like to thank Quaid-e-Awam University of Engineering, Science and Technology, Nawabshah for the financial support to complete the fabrication of the long-term testing frames and casting, compacting, baking, reinforcing, and testing of Reinforced Baked Clay (RBC) beams under long-term sustained loads.

\section{References}

1. Houben, H. and Guillard, H., Earth Construction: A Comprehensive Guide, Intermediate Technology Publication (1994).

2. Somayaji, S., Civil Engineering Materials, Prentice Hall (2001).

3. Varghese, P.C., Building Construction, PHI Learning (2007).

4. Kreh, R.T., Masonry Skills, Delmar Cengage Learning (2014).
5. Ansari, A.A. and Lakho, N.A. "Determination of structural properties of baked clay as replacement of RCC", Int. J. of Emerg Tech. and Adv Engg., 3(2), pp. 17-25 (2013).

6. Memon, M. and Ansari, A.A. "Management aspects of building construction using RBC", 1st Int. Conf. on Engg., Manage., Benchmarking Manage., Pract., in Devel., Countries, Mehran University of Engineering \& Technology Jamshoro, Sindh, Pakistan, pp. 103-108 (2008).

7. Ansari, A.A. "Experimental study of the behaviour of pre-perforated post-reinforced baked clay panels of beams", PhD Thesis. Department of Civil Engineering Quaid-e-Awam University of Engineering Science \& Technology, Nawabshah (2008).

8. Ansari, A.A., Memon, M. and Khaskheli, G.B. "Preperforated post-reinforced structural panels of baked clay as cheaper alternative of RCC construction", Procedia Engineering, 14, pp. 2635-2641 (2011). DOI: 10.1016/j.proeng.2011.07.331.

9. Nurnbergerova, T., Krizma, M. and Hajek, J. "Longterm deflections of reinforced concrete beams", Indian J. of Engg. and Mater Sci., 7(1), pp. 29-34 (2000).

10. Gambhir, M.L., Fundamentals of Structural Steel Design, McGraw Hill Education Private Limited, New Delhi (2013).

11. Castel, A., Gilbert, R.I. and Ranzi, G. "Instantaneous stiffness of cracked reinforced concrete including steel-concrete interface damage and long-term effects", J. Struct. Eng., 140(6), pp. 04014021 (2014). DOI: http://dx.doi.org/10.1061/(ASCE)ST.1943-541X. 0000954 .

12. Miàs, C., Torres, L., Turon, A. and Barris, C. "Experimental study of immediate and time-dependent deflections of GFRP reinforced concrete beams", Composite Struct., 96, pp. 279-285 (2013). DOI: 10.1016/j.compstruct.2012.08.052.

13. Miàs, C., Torres, L., Guadagnini, M. and Turon, A. "Short and long-term cracking behaviour of GFRP reinforced concrete beams", Composites Part B: Engineering, 77, pp. 223-231 (2015).

14. Han, Q.J., Zhu, H.T. and Cui, H.B. "Studies on longterm deflection of FRP reinforced concrete beams", Appl. Mech. and Mater., 438, pp. 811-814 (2013).

15. Choi, W.C. and Yun, H.D. "Long-term deflection and flexural behavior of reinforced concrete beams with recycled aggregate", Mater. and Des, 51, pp. 742-750 (2013).

16. Park, Y., Abolmaali, A., Attiogbe, E. and Lee, S.H. "Time-dependent behavior of synthetic fiberreinforced concrete pipes under long-term sustained loading", Transportation Research Record: J. of the Transpot. Res Board, 2407(1), pp. 71-79 (2014).

17. Aslani, F., Nejadi, S. and Samali, B. "Long-term flexural cracking control of reinforced self-compacting concrete one way slabs with and without fibres", Comput. and Concrete, 14(4), pp. 419-444 (2014). 
18. Castel, A. and Gilbert, R.I. "Influence of timedependent effects on the crack spacing in reinforced concrete beams", Struct. Concrete, 15(3), pp. 373-379 (2014).

19. Li, X., Gu, X., Ouyang, Y. and Song, X. "Longterm behavior of existing low-strength reinforced concrete beams strengthened with carbon fiber composite sheets", Composites Part B: Engg., 43(3), pp. 16371644 (2012).

20. Zerbino, R.L. and Barragan, B.E. "Long-term behavior of cracked steel fiber-reinforced concrete beams under sustained loading", ACI Mater. J., 109(2), pp. 215-224 (2012). DOI: 10.14359/51683708.

21. Zhang, Y. and Zheng, Y. "Long-term deflections of crushed limestone sand concrete beams.", $A d v$. in Struct. Engg, 16(9), pp. 1535-1544 (2013). DOI: 10.1260/1369-4332.16.9.1535.

22. Al-Sunna, R., Pilakoutas, K., Hajirasouliha, I. and Guadagnini, M. "Deflection behaviour of FRP reinforced concrete beams and slabs: An experimental investigation", Composites Part B: Engineering, 43(5), pp. 2125-2134 (2012).

23. Du, C., Liu, T., Zou, D. and Teng, J. "Time dependent strain development of early age concrete under step-by-step load history", Constr. and Build. Mater., 86, pp. 133-139 (2015). DOI: 10.1016/j.conbuildmat.2015.03.116.

24. Ranzi, G., Al-Deen, S., Ambrogi, L. and Uy, B. "Longterm behaviour of simply-supported post-tensioned composite slabs", J. of Constr. Steel Res., 88, pp. 172180 (2013). DOI:10.1016/j.jcsr.2013.05.010.

25. Gribniak, V., Bacinskas, D., Kacianauskas, R., Kaklauskas, G. and Torres, L. "Long-term deflections of reinforced concrete elements: accuracy analysis of predictions by different methods", Mech. of TimeDependent Mater., 17(3), pp. 297-313 (2013).

26. Gribniak, V., Cervenka, V. and Kaklauskas, G. "Deflection prediction of reinforced concrete beams by design codes and computer simulation", Engg. Struct, 56, pp. 2175-2186 (2013).

27. Castel, A., Gilbert, R., Ranzi, G. and Foster, S. "A non-linear steel-concrete interface damage model for reinforced concrete after cracking", Aust. J. of Struct. Engg, 15(2), pp. 221-229 (2014).
28. Kim, S. "Creep and shrinkage effects on steel-concrete composite beams", MSc Thesis. The Virginia Polytechnic Institute and State University (2014).

29. Jafarifar, N. "Shrinkage behaviour of steel-fibrereinforced-concrete pavements", $\mathrm{PhD}$ Thesis, University of Sheffield (2012).

30. Aktan, E.A., Gogate, A.B., Polak, M.A., et al., Control of Deflection in Concrete Structures, ACI (2003).

31. Gilbert, R.I. and Ranzi, G. Time-Dependent Behaviour of Concrete Structures, CRC Press (2010).

32. Ghali, A., Favre, R. and Elbadry, M. Concrete Structures: Stresses and Deformations: Analysis and Design for Serviceability, CRC Press (2006).

33. ASTM C62-13a., Standard Specification for Building Brick (Solid Masonry Units Made From Clay or Shale), ASTM International, West Conshohocken, PA (2013).

\section{Biographies}

Nawab Ali Lakho obtained ME in Irrigation and Drainage Engineering in 1999 from Mehran University of Engineering and Technology, Jamshoro, Pakistan. He serves as an Assistant Professor at the Department of Civil Engineering, Quaid-e-Awam University of Engineering, Science, and Technology (QUEST), Nawabshah, Pakistan. $\mathrm{He}$ is a doctoral student in Structural Engineering at QUEST Nawabshah. His research interests include the structural properties of Reinforced Baked Clay (RBC) as a substitute of reinforced cement concrete for construction of low-cost houses.

Muhammad Auchar Zardari received $\mathrm{PhD}$ from Lulea University of Technology, Lulea, Sweden in 2013 in Soil Mechanics and Foundation Engineering. Presently, he is an Assistant Professor at the Department of Civil Engineering, Quaid-e-Awam University of Engineering, Science and Technology, Nawabshah, Pakistan. His research interests include stability of embankment dams, internal erosion of dams, and utilization of waterlogged soils for foundations of buildings. 